\title{
MODELS FOR ANALYSIS OF IMPACT OF THE E-COMMERCE ON INDICATORS OF ECONOMIC DEVELOPMENT OF UKRAINE, POLAND AND AUSTRIA
}

E-commerce today is a separate area of e-business based on all forms of trade in goods and services through the using of electronic media including the Internet. The Internet and e-commerce lead to efficiency improvements, better asset utilization, faster time to market, reduction in total order fulfillment times, and enhanced customer service. The article describes the role of e-commerce as a promising industry in the Ukrainian economy and explores the main trends in the development of e-commerce in the world. Economic-mathematical models of the influence of ecommerce parameters on the indicators of economic development of the Austria, Poland, and Ukraine such as unemployment rate and GDP are constructed on the basis of the production function. The purpose of the article is to construct an economic and mathematical tool for studying the impact of e-commerce on indicators of economic development of the country. The research used the methods of scientific analysis, description, and synthesis in determining the main trends and characteristics of the development of e-commerce in the world; during the construction of economics and mathematical models to identify the impact of e-commerce on indicators of economic development of the country-methods of modeling and statistical analysis. The production function of Koba-Douglas was used in the study of the relationship between the parameters characterizing electron commerce and the indicators reflecting economic development. Calculations and mathematical operations were carried out in Excel and $R$ Studio environments. The main world tendencies of e-commerce development are considered and the main indicators of the e-commerce sector in Ukraine, Poland and Austria are compared. Economic and mathematical models on the influence of electronic commerce parameters on the unemployment rate and on the gross domestic product of Ukraine, Poland, and Austria as indicators of development of countries have been constructed. The study of statistical data confirmed the rapid growth of e-commerce and its impact on the indicators of economic development in the world. We found that at this stage the Austrian e-commerce market is a leader. However, the pace of e-commerce development in Ukraine and Poland exceeds this indicator in Austria, as the e-commerce markets in Ukraine and Poland are at the stage of formation and active growth. The simulation showed that the growth of the Internet-trade per capita contributes to reducing unemployment in Ukraine and Poland, but in Austria, on the contrary, this phenomenon causes an increase in this indicator. The results of the simulation indicate that e-commerce has an impact on the country's development and contributes to an increase in the gross domestic product in all three countries.

Keywords: e-commerce, e-business, e-trade, production function, economic development.

Introduction. E-commerce today is a separate area of e-business based on all forms of trade in goods and services through the using of electronic media including the Internet. The Internet and e-commerce lead to efficiency improvements, better asset utilization, faster time to market, reduction in total order fulfillment times, and enhanced customer service [1]. E-commerce fosters direct access to distant markets and promotes globalization of commercial activities, and blurs many of the current distinctions between domestic and foreign companies to an extent that it becomes practically impossible to determine the origin of products [2].

E-commerce has made communications and collaboration between companies easy and inexpensive, e-commerce allows intangible assets to be leveraged across a much larger buyer base. As e-commerce offers a model with no more time and space constraints, companies no longer have to co-locate with the tangible means of production. The introduction on the internet allows sellers to be able to get insight on 
their customer's habits and hopes, not only at a segment level but an individual level, translating into quality targeted products and services being offered to clients. The other main aspect that the internet has revolutionized is the availability of an extensive array of resources about any given product to the client [3].

Information and communication affect both the supply and demand sides. ICT have effects on the economic behavior of consumers through the utility function on the demand side, and it is also influential on the producer treatment on the supply side. The relationship between ICT and economic growth and efficiency on the supply side of the economy is determined by some complementary factors including organization and management experience, organizational and legislative part, and communications structure as an output on the supply side of the economy, among other factors entering into the capital, thereby leading to the improvement of the production process through capital deepening, advances in technology, and the quality of the labor force. As a result, the value added to output at three levels of the enterprise, sector, and country will be increased; ultimately, it will lead to economic growth, labor productivity growth, profitability and the welfare of the consumer [4].

The pace of development and distribution of e-commerce deserve for a special attention: each year the speed of distribution of this sphere increase. It is anticipated that by the end of 2018 the total sales of online stores around the world will reach $\$ 2$ trillion. The growth compared to 2017 will be $6 \%$ [5].

Almost half of all e-commerce sales in 2017 were generated by China ( $47 \%$ or $\$ 900$ billion). Thus, this country ranks first place in the world by the level of sales in Internet commerce.

The second largest regional market in the field of e-commerce in North America. The sales in the US and other countries in the region amounted to $\$ 423$ billion, showing an increase of $15.6 \%$ in 2017 .

According to the forecasts, the Asia-Pacific region will continue to be the largest regional e-commerce market and reach, according to various estimates, a turnover of $\$ 2,5$ to $\$ 2,7$ trillion to 2020 .

One of the main trends of the e-commerce market is the expansion of payment options. Many proprietors of leading online stores use traditional payment instruments, but the demand for innovative payment methods is increasing. A step closer to this demand is the strongest expansion of online retailing such as Apple Pay with its system of contactless payments [5-7].

Research. The study on the prospects for the development of e-commerce and its impact on economic development was engaged by foreign and domestic scholars like R. Anvari [4], D. Norouzi [4], N. Terzi [4], D. lorrnem [2], Y. Vasilyev [10] and others.

Purpose of the study is to construct an economic-mathematical tool for the study of the impact of ecommerce on the indicators of economic development of the country.

Research results. E-commerce is one of the most dynamic markets and part of a small number of those segments of the economy that continue to grow and develop despite the crisis, currency jumps and other problems faced by the economies of different countries in recent years. By 2020, the total Internet sales in the world should be about $\$ 4$ trillion [5] as shown in Fig. 1.:

According to Eurostat, the online trade segment accounts for more than $15 \%$ of all retail sales in the B2C segment in the European Union. The Internet Trade center in Europe is the UK. The volume of online sales in the $\mathrm{B} 2 \mathrm{C}$ area in the UK is higher than in the second biggest continental market in Germany three times. The leading platform here is Amazon, which generates $54 \%$ of all sales [8].

The main problems according to analysts are able to limit market growth in the future are security and privacy issues.

One of the peculiarities of e-commerce in Ukraine is that this business is extremely attractive to investors due to the low level of necessary first-rate investments, but the problems in this area include the underdevelopment of the telephone infrastructure in Ukraine, the lack of knowledge of entrepreneurs in the market, the failure of a new generation of managers and service personnel who is able to work in the market of electronic services [3]. 
T. Zatonatska. Models for Analysis of Impact of the E-Commerce on Indicators of Economic Development of Ukraine, Poland and Austria

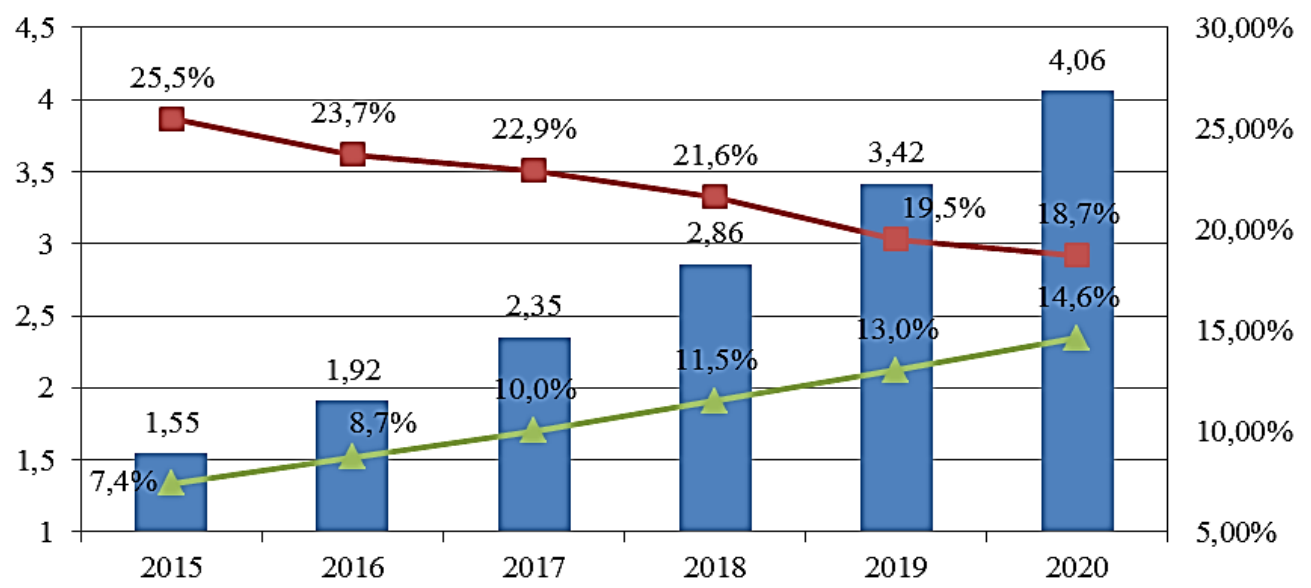

E-commerce sales, \$ trillion $\quad-$ Growth rates of e-commerce, \%

- Share of e-commerce in retail, $\%$

Figure 1 - Dynamics and forecast of e-commerce sales, growth rates and share in retail in the world, 2015-2020 (based on World Bank, Eurostat)

The volume of the e-commerce market in Ukraine for the period from 2014 to 2017 has increased from $\$ 19$ billion up to $\$ 46$ billion (by 2,5 times or by $142 \%$ ) [6].

The main problems to electronic shopping in Ukraine are the fear of mistakes, the lack of trust for online stores, the lack of need for online shopping and the desire to see the product before the purchase. However, it should be noted that the domestic e-commerce market continues to grow, and its growth rates are among the highest in Europe [8].

If we compare the e-commerce parameters in Ukraine, Poland and Austria, then we can say that the leader in the volume of Internet commerce per capita in Austria with an indicator of $\$ 1220$ per person in 2017 (Fig. 2).

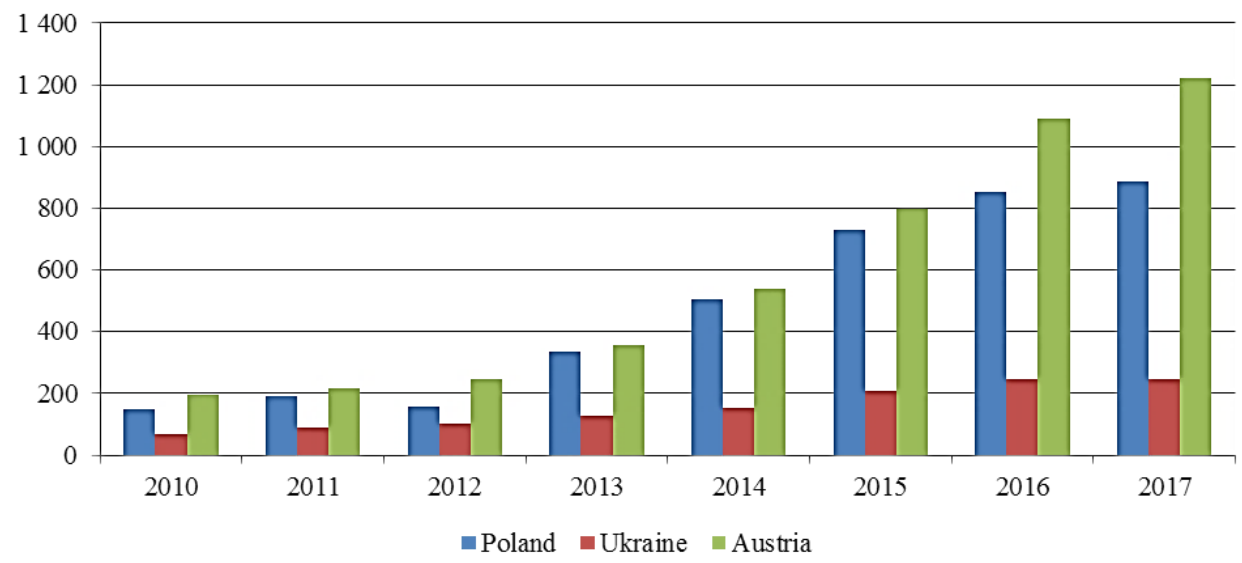

Figure 2 - Dynamics of Internet sales in Austria, Poland and Ukraine in 2010 - 2017, USD per capita (based on World Bank, Eurostat) 
Ukraine is in the last position with trade volumes via the Internet in 2017 of $\$ 248$, Poland in the second round with a sales volume of $\$ 885$ per person.

If we compare the share of Internet commerce in the country's GDP in 2010-2017 (table 1.), we can see that the ratio of this e-commerce parameter in certain countries changed with each passing year. Poland for many years had the largest share of Internet sales in GDP, but in 2017 Austria ranked first with $7,3 \%$, while Ukraine was the second with 7,1\% [9;10]. It should be noted that in Ukraine electronic commerce has started to develop later than in European neighbors, but the rapid growth of the share of online sales in GDP of the country testifies to the high rates of e-commerce expansion and growth of its importance on the domestic market.

Table 1 - The share of Internet trade in GDP of the countries in 2010 - 2017 (World Bank, Eurostat, Minfin, State Statistics Committee)

\begin{tabular}{|l|c|c|c|}
\hline \multirow{2}{*}{ Year } & \multicolumn{3}{|c|}{ Country } \\
\cline { 2 - 4 } & Ukraine & Poland & Austria \\
\hline 2010 & $0.52 \%$ & $3.03 \%$ & $1.38 \%$ \\
\hline 2011 & $0.73 \%$ & $2.89 \%$ & $1.67 \%$ \\
\hline 2012 & $0.95 \%$ & $3.87 \%$ & $2.23 \%$ \\
\hline 2013 & $1.31 \%$ & $4.61 \%$ & $2.89 \%$ \\
\hline 2014 & $2.42 \%$ & $4.85 \%$ & $3.58 \%$ \\
\hline 2015 & $4.78 \%$ & $6.48 \%$ & $5.43 \%$ \\
\hline 2016 & $5.93 \%$ & $7.32 \%$ & $6.63 \%$ \\
\hline 2017 & $7.12 \%$ & $6.82 \%$ & $7.30 \%$ \\
\hline
\end{tabular}

For a detailed analysis, other indicators determining the degree and rate of e-commerce development in each of the three countries were compared (table 2). Comparing the number of Internet users, we can see that Poland is the leader and Ukraine is second (with 29 and 27 million people by 2017). However, such a comparison is not very informative since the total population in Ukraine and Poland significantly exceeds the population in Austria. Therefore it is more appropriate to pay attention to the rate of Internet penetration in the country, as the ratio of the number of Internet users to the total population. And then we can conclude that Austria last year with an index of $85 \%$ (1\% increase compared with 2016) has become one of the leading countries in Europe for this parameter. Poland and Ukraine ( $77 \%$ and $65 \%$ respectively) are lagging behind Austria, but there is also a significant increase in Internet users every year: in 2016 the Internet penetration in Poland was 73,3\% (6\% increase), in Ukraine 52,5\% (23,4\% increase in 2017) [6;11].

Table 2 - Comparison of key e-commerce indicators in Ukraine, Poland and Austria in 2017 (World Bank, Eurostat, Minfin, State Statistics Committee)

\begin{tabular}{|l|l|c|c|c|}
\hline \multirow{2}{*}{ Indicators } & \multicolumn{3}{|c|}{ Country } \\
\cline { 3 - 5 } \multicolumn{2}{|c|}{} & Ukraine & Poland & Austria \\
\hline Number of Internet users & thousand people & 27477 & 29388 & 7340 \\
\hline Internet penetration & $\%$ of population & 65 & 77 & 85 \\
\hline \multirow{2}{*}{ Internet sales } & million USD & 6808 & 35064 & 29873 \\
\cline { 2 - 5 } & USD per person & 248 & 885 & 1220 \\
\hline \multirow{2}{*}{ A growth rate of e-commerce } & $\%$ & 23 & 2 & 15 \\
\hline \multirow{2}{*}{ Number of Internet buyers } & thousand people & 13569 & 12527 & 4577 \\
\cline { 2 - 5 } & $\%$ of population & 32 & 33 & 53 \\
\hline
\end{tabular}


As we can see from table 2. Ukraine is the undisputed leader in the growth rate of e-commerce. Moreover, this indicator remains one of the highest in Europe for several years.

The number of Internet buyers is also more appropriately compared in terms of percentage of total population. Again, Austria is leading it with an index of 53\%. Ukraine and Poland are approximately in the same position with regard to the number of people who make online purchases with $32 \%$ and $33 \%$ respectively.

Taking into account the rapid development of the sphere of Internet commerce worldwide, it is expedient to determine the degree of influence of e-commerce on indicators of economic development of the country. To do this, we try to build economic-mathematical models to determine the dependencies between e-commerce and country development on the example of Austria, Poland and Ukraine and compare the results. For this purpose, it is proposed to use the Cobb-Douglas function [12; 13].

The production function of Cobb-Douglas is a convenient tool in the economy, which reflects the link between the volume of production and production factors - labor and capital. This model will be used in the study of the relationship between the parameters characterizing the e-commerce and the variable reflecting economic development.

Calculations and mathematical operations were carried out in Excel and R Studio environments. In the course of the study, two models were developed on the impact of e-commerce on development and growth for each country. The data series was built on the basis of statistical data for the period from 2000 to 2017 , annual data was taken. $[6 ; 7 ; 11 ; 14]$

Let's analyze the first model. For its construction, the volume of the Internet - trade in billion dollars was taken, the volume of the Internet - trade per capita in dollars per person and number of Internet buyers as a percentage of the total population as parameters reflecting the level of e-commerce development in the country. As a dependent variable, the unemployment rate in the country in percentage is selected.

An Augmented Dickey-Fuller test (ADF - test) was used for testing the stationarity of the series. The low value of the $p$-value indicates the stationarity of the time series.

The mathematical interpretation of the model is as follows:

$$
\ln U p l=\ln A+\beta \ln I T p e r+\gamma \ln I C
$$

where $U p l$ - unemployment rate; $A$ - a certain stable coefficient characterizing the unemployment rate that prevails in the country without the influence of e-commerce factors and the Internet; ITper - the volume of the Internet - trade per capita; IC - the number of the Internet-buyers; $\beta, \gamma$ - coefficients of elasticity of independent variables.

The assumption of multicollinearity was rejected using the VIF criterion. The lack of autocorrelation was confirmed using the Breush-Godfrey test. Also, models have no heteroscedasticity that indicated by the White test. All models have no specification errors that tested by using the RESET test.

An important point is that using this model gives the ability to scale expression and growth rate of the dependent variable by interpretation of elasticity coefficients.

The model built for Ukraine has the following form:

$$
\ln U p l=1.854-0.116 \ln I T p e r_{u k r}+0.02 \ln I C_{u k r}
$$

The main parameters of the model are given in Table 3. Thus, the elasticity of the level of unemployment to the volume of the Internet-trade per capita in Ukraine is - $0,116 \%$ (reverse dependence), which means a decrease in unemployment rate with the growth of this indicator per unit. The direct dependence in the model is obtained only in case of changes in the number of Internet buyers: when this parameter increases by one, the level of unemployment increased by $0,02 \%$. The sustainable coefficient 
is 1,986 points to the unemployment rate in Ukraine without taking into account the influence of all factors or in the absence of them.

\begin{tabular}{|c|c|c|c|}
\hline Country & Variables & Coefficients value & $p$-value \\
\hline \multirow{5}{*}{ Ukraine } & $\operatorname{Ln} A$ & 1.854 & 0.00382 \\
\hline & Ln ITper & -0.116 & 0.00236 \\
\hline & $\operatorname{Ln} I C$ & 0.02 & 0.00211 \\
\hline & F-test value & 13.354 & \\
\hline & $R^{2}$ value & 0.651 & \\
\hline \multirow{5}{*}{ Poland } & $\operatorname{Ln} A$ & 0.1719 & 0.00361 \\
\hline & Ln ITper & -0.200 & 0.00256 \\
\hline & $\operatorname{Ln} I C$ & -0.069 & 0.00483 \\
\hline & F-test value & 15.674 & \\
\hline & $R^{2}$ value & 0.752 & \\
\hline \multirow{5}{*}{ Austria } & $\operatorname{Ln} A$ & 0.752 & 0.00238 \\
\hline & Ln ITper & -0.182 & 0.00114 \\
\hline & $\operatorname{Ln} I C$ & 0.257 & 0.00274 \\
\hline & F-test value & 14.738 & \\
\hline & $R^{2}$ value & 0.649 & \\
\hline
\end{tabular}

In the analysis of the model, we should pay attention to the coefficient of determination $R^{2}=0,508$, which indicates weak relationships between variables. All the coefficients near the variables are significant (with significance level $\alpha=0,95$ ).

The similar simulation methods and tests for analysis were also used to construct the models for Poland and Austria. The simulation results are given in a table. 3

In mathematical form the model for Poland has the following form:

$$
\ln U p l=1.719-0.052 \ln \text { ITper }_{p o l}+0.26 \ln I C_{\text {pol }}
$$

The Augmented Dickey-Fuller test has helped to determine that the time series of the model are stationary. The reverse dependence on the model for Poland's indicators is observed between the elasticity of the level of unemployment on the volume of the Internet-trade per capita. With an increase in the number of online buyers per unit in Poland the unemployment rate in accordance with the model will decrease by $0,069 \%$.

The model in mathematical terms for Austria looks like this:

$$
\ln U p l=0.752-0.102 \ln I T p e r_{a u s}+0.257 \ln I C_{a u s}
$$

In Austria also there is a reverse relationship between the amount of Internet - trade per capita and the unemployment rate: the elasticity of the unemployment rate to this parameter is $-0,102 \%$, which means that with increasing of volume of Internet - trade per capita per unit unemployment rate in Austria will decrease by $0,102 \%$. With regard to the elasticity of the unemployment rate to the number of Internet buyers, the figure is $0,257 \%$. Without taking into account all factors, the unemployment rate in Austria will be 0,752 .

By comparing the simulation results for the three countries, we can say that the strongest link between dependent and independent variables is present in the model for Poland.

Comparing all the models it can be said that the influence of the e-commerce factor is more pronounced for Ukraine and Poland because in these countries the degree of penetration of the Internet 
and the volume of Internet trade are much smaller than in Austria. However, this also indicates the availability of broad opportunities for the development of this industry, because, for example, in Ukraine, the growth rate of e-business is one of the highest in the EU.

Thus, the available results make it possible to affirm that the constructed models can be used in future studies. With such models, we can explore the link between e-commerce parameters and the country's development indicator.

The next three models were constructed to investigate the dependence between e-commerce parameters and the economic growth of comparable three countries. The volume of the Internet-trade in billion dollars and the Internet penetration (as a share of a population using the World Wide Web in the total population of the country) was chosen as independent variables. As a dependent variable, the country's GDP in millions of dollars was chosen. The values of the parameters are taken from 2000 to 2017 as in previous models $[6 ; 7 ; 11 ; 14]$.

The general view of this model in the mathematical term is represented by the following equation:

$$
\ln G D P=\ln M+\varphi \ln I T+\lambda \ln I P
$$

where GDP - GDP; $M$ - a certain constant coefficient; IP - Internet penetration; IT - the volume of the Internet-trade; $\varphi, \lambda$ - coefficients of elasticity of independent variables.

All-time series that used in models were tested for stationarity by Augmented Dickey-Fuller test that indicated their stationarity.

For Ukraine, the model has the following form:

$$
\ln G D P_{u k r}=14.944+0.058 \ln I T_{u k r}+0.368 \ln I P_{u k r}
$$

So the elasticity of GDP to the volume of the Internet - trade is $0,058 \%$ (direct dependence), that is the growth of the volume of trade by the Internet will lead to an increase in GDP of Ukraine by $0,058 \%$. The elasticity of GDP to the Internet penetration is $0,368 \%$, which suggests that an increase in the percentage of Internet users will contribute to an increase in GDP by $0,37 \%$.

If we analyze the sum of the coefficients of elasticity we can see that $\varphi+\lambda=0,058+0,368=0,624$, so for the period under review, the combined influence of the factors contributed to a significant increase in the dependent variable.

In the analysis of the model first, we look at the coefficient of determination $R^{2}=0,583$, which indicates a weak link between the variables. All the coefficients near the variables are significant (with significance level $\alpha=0,95)$. The correlation coefficient between the variables $r=\sqrt{R^{2}}=\sqrt{0,583}=0,764<$ 0,9 is not high, but we can say about the weak dependence between variables.

The main parameters of the model are shown in a table. 4.

Let's compare the degree of the influence of e-commerce to the economic development of Poland and Austria. The mathematical model of e-commerce and GDP in Poland is as follows:

$$
\ln G D P_{p o l}=14.022+0.145 \ln I T_{p o l}+0.084 \ln I P_{p o l}
$$

Thus the constant coefficient of the model reflecting the GDP in the country in the absence of all factors is 14,022 . The coefficient of GDP elasticity to the volume of the Internet - trade in this country is $0,145 \%$, which indicates an increase of GDP of Poland by $0,145 \%$ with the changing of Internet sales per unit. If we look on the elasticity of GDP to the parameter of Internet penetration we can see that there is a direct dependence: the changing of this indicator per unit leads to an increase in GDP by $0,084 \%$. 
Table 4 - Simulation results for Ukraine, Poland and Austria

\begin{tabular}{|c|l|c|c|}
\hline Country & Variables & Coefficients value & p-value \\
\hline \multirow{4}{*}{ Ukraine } & $\operatorname{Ln} M$ & 14.944 & $2.986 \mathrm{E}-05$ \\
\cline { 2 - 4 } & $\operatorname{Ln} I T$ & 0.058 & 0.00084 \\
\cline { 2 - 4 } & Ln IP & 0.368 & 0.00323 \\
\cline { 2 - 4 } & F-test value & 10.472 & \\
\cline { 2 - 4 } & $\mathrm{R}^{2}$ value & 0.583 & \\
\hline \multirow{5}{*}{ Poland } & $\operatorname{Ln} M$ & 14.022 & $1.843 \mathrm{E}-17$ \\
\cline { 2 - 4 } & $\operatorname{Ln} I T$ & 0.145 & 0.00011 \\
\cline { 2 - 4 } & $\operatorname{Ln} I P$ & 0.084 & 0.40142 \\
\cline { 2 - 4 } & F-test value & 14.596 & \\
\cline { 2 - 4 } & R 2 value & 0.851 & \\
\hline \multirow{5}{*}{ Austria } & $\operatorname{Ln} M$ & 16.179 & $1.237 \mathrm{E}-19$ \\
\cline { 2 - 4 } & $\operatorname{Ln} I T$ & 0.078 & 0.00996 \\
\cline { 2 - 4 } & Ln IP & 0.016 & $2.972 \mathrm{E}-10$ \\
\cline { 2 - 4 } & F-test value & 18.876 & \\
\cline { 2 - 4 } & R 2 value & 0.862 & \\
\hline
\end{tabular}

The high value of the coefficient of determination $R^{2}=0,851$ means that there is a close relationship between variables. And the sum of the coefficients of elasticity $\varphi+\lambda=0,145+0,084=0,229$ indicates the growth of the dependent variable with the influence of factors for the period under consideration.

If we consider the model of the impact of e-commerce on Austria's GDP we obtain the following mathematical equation:

$$
\ln G D P_{\text {aut }}=16.178+0.078 \ln I T_{\text {aut }}+0.016 \ln I P_{\text {aut }}
$$

The constant variable $(16,178)$ reflects the highest rate of GDP in all three countries without taking into account e-commerce factors. If we consider the elasticity of GDP to the volume of Intranet - trade, and penetration of the Internet in Austria, we can see that the data figures are respectively $0,078 \%$ and $0,016 \%$. That indicates a GDP growth of $0,078 \%$ and $0,016 \%$ with an increase in Internet sales and Internet penetration per unit, respectively.

The determination coefficient is also high in this model $R^{2}=0,862$, as well as the correlation coefficient between variables $\left(r=\sqrt{R^{2}}=\sqrt{0,862}=0,928>0,9\right)$ and indicates a strong link between the indicators.

In all models using the VIF-criterion to the resulting model gave grounds for rejecting the assumption of multicollinearity between variables. The lack of auto-correlation was confirmed using the BreushGodfrey test. Also, White's test indicated an absence of heteroscedasticity.

If we compare the elasticity parameters in the models we can see that the degree of influence of ecommerce indicators on economic growth is the weakest in Austria. At the same time, the Ukrainian model shows the high sensitivity of the country's gross domestic product to the rate of the Internet penetration, while Poland's GDP is sensitive to the volume of trade through the Internet. In addition, the model for Ukraine has shown the weakest link between variables, but its presence cannot be denied.

Thus, the second model is also relevant for using and tracking of the dependence between ecommerce parameters and economic growth.

Model analysis has proved that their using is appropriate for tracking the relationship between these indicators. The models reflect the logical impact of e-commerce development on reducing unemployment in Ukraine and Poland, but for Austria, the situation is reversed.

Conclusions. During the study, the main world trends in e-commerce development were considered; it gave the possibility to prove the rapid growth of this sector of the economy and its impact on the indicators 
T. Zatonatska. Models for Analysis of Impact of the E-Commerce on Indicators of Economic Development of Ukraine, Poland and Austria

of the economic development of the countries in the world. Based on the comparison of key indicators of the e-commerce sector in Ukraine, Poland, and Austria, it has been determined that the Austrian ecommerce market is the leader at this stage. However, the pace of e-commerce development in Ukraine and Poland exceeds this indicator in Austria, as e-commerce markets in Ukraine and Poland are at the stage of formation and active growth.

In the study it was found that the simulation of the behavior of certain indicators shows the existing differences: for example, the growth of Internet sales per capita contributes to reducing of the unemployment rate in Ukraine and Poland, but in Austria, on the contrary, this phenomenon will cause an increase of this indicator. Perhaps this situation is due to the fact that Austria, in comparison with Ukraine and Poland, has a higher level of informatization in the branches of the economy. Therefore, the development of e-commerce in Ukraine and Poland will help to create new jobs and increase employment, while in Austria, the rapid growth of Internet transactions and automation of their processing will lead to a decreasing in it.

In the simulation of the dependence between e-commerce indicators such as the volume of the Internet-rade, Internet penetration, and the country's GDP growth rate we found that the degree of influence of e-commerce indicators on economic growth is the weakest in Austria. At the same time, the Ukrainian model shows the high sensitivity of the country's gross domestic product to the penetration rate of the Internet, while Poland's GDP is sensitive to the volume of trade through the Internet.

The results of the simulation indicate that e-commerce has an impact on the country's development and contributes to an increase in the gross domestic product in all three countries.

1. Terzi, N. (2011). The impact of e-commerce on international trade and employment. Procedia-Social and Behavioral Sciences, 24, 745-753. Available at: https://fardapaper.ir/mohavaha/uploads/2017/10/The-impact-of-e-commerce-on-internationaltrade-and-employment.pdf (Accessed 06 September 2018).

2. lorrnem, D. (2017). The impact of e-commerce infrastructure, online trust and security on effective digital marketing implementation in Nigeria, available at: http://www.stclements.edu/grad/gradiornem.pdf (Accessed 06 September 2018).

3. The website "Aladdin Jinnie". (2017). Impact of e-Commerce in Today's Business World, available at: http://aladdinjinnie.com/blog/2017/03/24/impact-of-e-commerce-in-todays-business-world/ (Accessed 06 September 2018).

4. Anvari, R. D., \& Norouzi, D. (2016). The impact of e-commerce and R\&D on economic development in some selected $\begin{array}{lllll}\text { countries. Procedia-Social and } & \text { Behavioral }\end{array}$ https://fardapaper.ir/mohavaha/uploads/2018/01/Fardapaper-The-Impact-of-E-commerce-and-RD-on-Economic-Development-inSome-SelectedCountries.pdf(Accessed 06 September 2018).

5. Fedorychak, V. (2018). Cikavifakty prointernet-torgivlyu v sviti v 2018 roci, available at:http://lemarbet.com/ua/razvitieinternet-magazina/interesnye-fakty-ob-internet-torgovle/(Accessed 06 September 2018).

6. The official site of the World Bank. World Development Indicators. (2018), available at: http://www.worldbank.org (Accessed 06 September 2018).

7. The Statistics Portal "Statista". (2018). available at: https://www.statista.com (Accessed 06 September 2018).

8. The website "Internet live stats". (2018). available at: http://www.internetlivestats.com (Accessed 06 September 2018).

9. Gawady, E., \& Mohamed, Z. (2005). The Impact of E-commerce on Developed and Developing Countries., available at:http://www.must.edu.eg/Publications/Businees_Res5.pdf (Accessed 06 September 2018).

10. Vasyliev Yu.Yu. (2017). Elektronna komerciya yak instrument prosuvannya tovariv na ry'nku pobutovoyi texniky' [Ecommerce as a tool for promoting products on the home appliance market]. International Scientific Journal "Internauka", 1, available at:https://www.inter-nauka.com/uploads/public/14849302088800.pdf(Accessed 06 September 2018).

11. Financial portal "Minfin". (2018). available at: https://minfin.com.ua/ua/ (Accessed 06 September 2018).

12. Dharmasiri, L. M., \& Datye, V. S. (2011). Application of Cobb-Douglas Function for Analyzing the Process of Agricultural Production: A Case Study from Sri Lanka. Transactions of the Institute of Indian Geographers, 33(2), 251-263, available at:https://www.researchgate.net/publication/241695593_Application_of_Cobb-Douglas_Function_for_Analyzing_the_Process_of_ Agricultural_Production_A_Case_Study_from_Sri_Lanka (Accessed 06 September 2018).

13. Simut, M. (2015). Estimating the Cobb Douglas production function including the export and openness in the case of Romania, available at: http://steconomiceuoradea.ro/anale/volume/2015/n1/072.pdf (Accessed 06 September 2018).

14. The official site of Eurostat. (2018), available at: http://ec.europa.eu/eurostat (Accessed 06 September 2018). 
Т. Г. Затонацька, дее.н., професор, Київський національний університет імені Тараса Шевченка (Киї̈в, Україна). Моделі аналізу впливу е-комериії на показники економічного розвитку України, Польщі, Австрії

у статті розелянуто сутність та роль електронної комериії як перспективної галузі в українській економіці та досліджено основні тенденції розвитку електронної комерції у світі. На основі виробничої функції побудовані економікоматематичні моделі впливу параметрів електронної торгівлі на показники економічного розвитку, рівень безробіття та ВВП Австрії, Польщі та України. Метою статтіє побудова економіко-математичного інструментарію дослідження впливу електронної комерції на показники економічного розвитку країни. У дослідженні при визначенні основних тенденцій та характеристик розвитку електронної комериії у світі, використано методи наукового аналізу, опису та синтезу; під час побудови економічних та математичних моделей для визначення впливу електронної комерції на показники економічного розвитку країни - методи моделювання та статистичного аналізу. За допомогою виробничої функиії КобаДугласа було оцінено взаємозв'язок між параметрами, що характеризують електронну торгівлю, та індикаторами, що відображають економічний розвиток. Розглянуто основні світові тенденції розвитку електронної комерції та здійснено порівняння основних показників сектору електронної торгівлі в Україні, Польщі та Австрії. За допомогою методів симуляції зроблено висновок, що зростання обсягів інтернет-торгівлі на душу населення сприяє зниженню безробіття в Україні та Польщі, та його зростанню в Австрії. Вивчення статистичних даних підтвердило гіпотезу про суттєве зростання обсягів електронної комериії та її вплив на показники економічного розвитку у світі. Ринки електронної комерції в Україні та Польщі знаходяться на стадії формування та активного зростання, а темпи розвитку електронної комерції в Україні та Польщі перевищують показник Австрії, визнаної лідером на даному ринку.

Ключові слова: електронна комерція, електронний бізнес, електронна торгівля, виробнича функція, економічний розвиток.

http://mmi.fem.sumdu.edu.ua/en 